\title{
Ethnographic information and anthropological interpretations in a native title claim: the Yorta Yorta experience
}

\author{
Rod $\mathrm{H}$ agen
}

Any anthropologist who has worked on Native Title claims, or similar activity, in southeastern Australia is likely to have come across the anger of Indigenous groups confronted with 'academic' interpretations of their rights, interests, customs and traditions which differ from their own view of these important aspects of their lives.

Native title claims, particularly, with their emphasis on the establishment of cultural 'continuities' with the situation at the time of initial white occupation, have the potential to further exacerbate such views.

Indigenous groups, not surprisingly, are highly indignant about having their claims, and the primarily oral traditions on which they are based, judged against the writings of the initial colonisers themselves and on occasion react even more strongly against later 'academic' interpretations of territorial interests, best epitomised perhaps by the work of $\mathrm{N}$ orman Tindale.

They are highly suspicious of the accuracy of much of the work of this type, and see it as cutting across the positive ethos of self-determination and self-empowerment which has characterised Indigenous affairs in recent decades.

On the other hand, groups such as the Yorta Yorta, on the Murray River between Echuca and Albury, with whom I have been working intermittently since late 1993, have found it necessary to come to terms with the importance of written ethnographic, anthropological and historical material in the course of preparation and presentation of their native title claim.

The case, and the relevant ethnographic and historical materials presented in the course of the claim, accordingly provide a good opportunity to assess the validity of Indigenous fears about such matters, and provide some guidance to practitioners concerning the sorts of problems which are likely to emerge with the treatment of such 'whitefella' materials.

This, in turn, has broader implications for disciplines such as anthropology and history. In the past it has been rare for the 'output' of academics and fellow travellers to be exposed to the heat of such an intense 'blowtorch' as, for example, the Yorta Yorta claim processes involving several hundred respondents and three State governments. 
This blowtorch is different in some respects from the normal debate and discourse within academia about such matters. Firstly, of course, it can have immediate real life consequences for the people concerned. Secondly, it tends to come through people who, though they may often lack sophisticated knowledge of the subject matter or the underlying theoretical principles of the disciplines concerned, make their living from attacking facts and arguments of all kind.

The Yorta Yorta (also sometimes identified as the 'Bangerang') traditionally hail from country on the Murray River along the New South Wales-Victorian border upstream from a little bel ow Echuca. They have a long and remarkable history of using non-Indigenous institutions and processes in attempts to obtain recognition of their interests. Within 25 years of the first white occupation of their lands in the late 1830s they were seeking compensation for the damage to their traditional fisheries caused by the introduction of paddlesteamers on the Murray River. Within 45 years they were involved in petitioning the government for formal title to parts of their lands. ${ }^{1}$

Men such as William Cooper, a prominent figure in the 1938 Day of Mourning protests and fondly remembered by community members today, were al ready making formal demands for recognition of their interests in land in the $1880 \mathrm{~s}^{2}$ In the late 1930s, three decades before the Gurindji wal ked off Wave Hill, the Yorta Yorta had done much the same thing at Cummeragunja. These matters are proudly remembered elements of the cultural history of the Yorta Yorta/ Bangerang today and since 1960 have received some academic recognition in the writings of people such as the late Diane Barwick, Professor CD Rowley, Nancy Cato and Heather Goodall.

Perhaps the most comprehensive recent discussion can be found in the work of $\mathrm{Dr}$ Wayne Atkinson, a senior Yorta Yorta man whose doctoral thesis dealt with important historical aspects of the Yorta Yorta claim processes ${ }^{3}$. Earlier works by Atkinson contain a wealth of first-hand material provided to him in the course of research in the 1970s and 80 s. $^{4}$

In my opinion, his unique perspective on the Yorta Yorta situation (as both elder and qualified historian) received less weight than it should in the course of claim hearings, with attacks made on his academic expertise by the Victorian and NSW State governments and other parties because of his membership of the claimant group, and on his ability to speak as a Yorta Yorta man on the basis of his academic skills and qualifications! If the expert evidence of Indigenous witnesses is to be regarded as necessarily 'tainted' because of close association with the Indigenous community, then perhaps, applying the same logic, non-Indigenous experts should be disqualified similarly from being taken seriously when 'white' matters are under discussion! This is an important issue, likely to raise its head again and again in similar situations. There are many eminent Indigenous scholars today whose standing should be seen as enhanced substantially by the symbiotic interplay of personal and academic knowledge. If we genuinely wish to understand these situations then we need to recognise this.

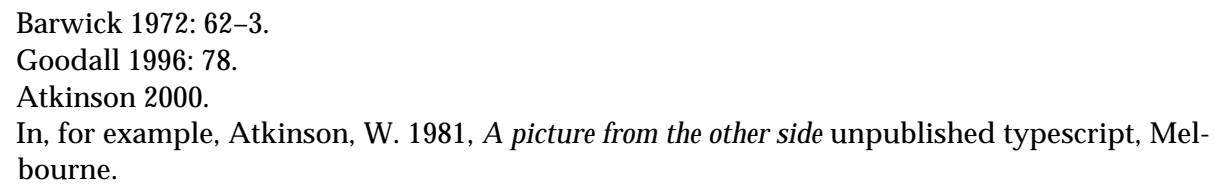


Before the growth of interest in the contemporary situation in the 1960s and 70s most of those writing about the Yorta Yorta, however, ignored the present in favour of a search for some essential past. One exception to this, perhaps, was the GA Robinson, who arrived in the area so soon after white occupation that such a dichotomy could have little meaning. I now turn to the work of some of the earlier ethnographers and anthropologists whose work arose in the course of the original claim hearings.

\section{GA Robinson, Chi ef Protector of A borigines}

The first significant documentation of the interests of Indigenous people in the area which the Yorta Yorta are today claiming as their traditional lands ${ }^{5}$ was undertaken by GA Robinson, the Chief Protector of Aborigines in Victoria in the 1840s. Robinson visited the area on several occasions, recording the identity of individuals and groups at various locations. His materials were later to be used by Diane Barwick in her own reinterpretations of traditional interests in the area.

Despite the limitations posed by the difficulties of reading Robinson's handwriting, which on occasion have led to differences of interpretation on matters of substance, his journals contains a wealth of information from the earliest days of settlement of the region. His work was ignored by anthropologists until Diane Barwick's rediscovery of him in the 1960s and her subsequent use of his work as a primary source for her 1980s reinterpretation of territorial interests in parts of Victoria. In more recent times he has also been used by Ian Clark in his various attempts at identification of territorial interests in Victoria.

The material is essentially devoid of theoretical sophistication. Although Robinson recognised that Indigenous groups operated on a variety of levels, he provides no elucidation of the principles of group recruitment or of other matters of structure or organisation. He generally called narrower groupings 'sections' and broad groups 'nations' and on occasion used the word 'tribe' for either. Sometimes his two primary levels become three, with intermediate aggregates of 'sections' identified by Indigenous names such as 'Quart Quart' which, in turn, are identified as subdivisions of broader 'nations'.

Interestingly, people that he met in his travels in the very first years of white settlement of the area, seem to bear little relationship to one of the classical models of Australian anthropology, developed by Radcliffe Brown in 1914. ${ }^{6} \mathrm{~N}$ owhere did he meet the 'patriclan plus spouses' groupings beloved of many writers in the 20th century. Instead, he commonly found people who identify with a variety of narrow groups, all living at the one place or travelling together for common purposes. There is little evidence in the earliest days of occupation, that 'clans', in the classical Australian anthropological sense, ${ }^{7}$ provided the real core of land using groups in this part of southeastern A ustralia.

5. When this paper was first presented in 1997, the Yorta Yorta claim had not yet been adjudicated on by Justice Olney. He found against their claim. An appeal to the full bench of theFederal Court was also unsuccessful (in a split decision). In October, 2001 the Yorta Yorta were awaiting hearing of an application for leave to appeal to the High Court of Australia.

6. Radcliffe-Brown 1914 'Three tribes of Western A ustralia'. 
Robinson identified two broad 'nations' occupying the bulk of the area claimed by the Yorta Yorta/ Bangerang today. One of these, his 'Pinegerine', has appeared frequently in the ethnographic and anthropological thereafter as the 'Bangerang' or 'Pangerang'. The other, his 'Waveroo', disappeared from view completely until Diane Barwick resurrected his materials in the early 1980s. No other 19th century commentator makes mention of them. Intriguingly too, in his journals the area which he ascribes to 'Waveroo' groups in a large measure overlaps the areas which he and other 19th century commentators such as Edward Curr also ascribe to the Bangerang, and he identifies members of both groups living and travelling together in all or almost all places which he visits in the region.

In the Yorta Yorta claim case, Robinson's materials were examined primarily by me and by a historian engaged by opponents of the claim, Marie Fels. Ronald Brunton, an anthropologist engaged by opponents of the claim, al so viewed some of the material. Unfortunately Ian Clark's transcription of most of the relevant journals had not been completed at that time, and we worked, for the most part, from poor copies of the original material, making effective use of its content painstakingly slow and open to argument. Justice Olney ultimately dismissed much of the expert discussion of Robinson on the basis that:

The Court is not in a position to resolve disputed questions of anthropological interpretation. None of the persons whose original observations and records are relied upon could be called to give evidence and accordingly no assessment can be made of the credibility of the primary material. There are no objective facts to which the Court can have regard to support a conclusion one way or the other. That being so, if scholars learned in the relevant discipline are unable to provide an authoritative answer, the Court must have resort to such credible primary evidence as is available and apply the normal processes of analysis and reason. ${ }^{8}$

He then proceeded to attempt his own anthropological and historical analysis of the materials.

His approach to this matter was very different from that in another recent Federal Court case. In a recently determined case in which damages were sought for delays in the construction of the Hindmarsh Bridge, Justice Von Doussa concluded that in such situations:

I do not think any useful purpose would be achieved by me endeavouring to assume the role of an anthropologist and trying to evaluate the large quantity of material placed before the Court at the selection of each of the parties. This is a case where I consider the dispute on anthropological matters should be resolved broadly on an acceptance of one or the other of the contrasting anthropological positions which the expert witnesses have articulated. ${ }^{9}$

There is much to be said for Von Doussa's approach to such matters.

7. Indigenous groups in south eastern Australia themselves often speak of 'clans' today. When they do so, however, they are al most al ways referring to much broader cognatic groupings than those contemplated by the Australian anthropological definition, which is narrow even compared to use of the term in the discipline internationally.

8. Olney, J, 'The members of the Y orta Y orta A boriginal community $v$ the State of Victoria and others', VG no 6001 of 1995.

9. Chapman v Luminis Pty Ltd (no 5) [2001] Federal Court of Australia 1106. 


\section{Edward Curr}

The next major figure in the ethnographic literature of the area is Edward Curr, pastoralist, sheep warden and author of one of the major tomes of 19th century ethnography, The A ustralian race. In this and in Recollections of a squatter in Victoria from 1841 to 1851, Curr sought to describe aspects of Bangerang life. He did so on the basis of his 40-yearold memories of his time as one of the first squatters amongst the giant redgums of the Moira and Barmah forests.

Despite the great delay between his observations and his writings (and his own confession that he took little interest in Aboriginal matters when he was living in the area), Curr paints a far more vivid picture of the Indigenous people of the area than that offered by Robinson. It is clear that for much of his material he relied heavily on the observations of others, though much of Recollections in particular is written in the form of a first-hand account.

With Curr we begin to see the more forceful intrusion of politics and western intellectual interests into the process of recording the life of the people of the region. Curr was in frequent conflict with figures such as R Brough Smyth. They disagreed on matters of both Aboriginal policy and ethnographic theory. In the midst of raging ethnographic debates about the evidence for the progression of social organisation from the simple to the complex, based, in part in turn, on social Darwinist theory, and of policy debates about relative merits of protectionism and assimilation, the two men took opposing sides. The white arguments over protection or assimilation of course lasted well into the twentieth century ${ }^{10}$ and the anthropological arguments about Indigenous hierarchy or egalitarianism have continued to the present day, as Les Hiatt has pointed out in his A rguments about A borigines (1996).

In the context of the present discussions, one is left wondering which parts of Curr's commentary of the Yorta Yorta/ Bangerang derive from genuine observation, and which are the product of a desire to bolster his own theoretical and political position.

Curr's depiction of Bangerang society places far greater stress on narrow patrifocal groups than Robinson's 'on the ground' identification of the people that he met on his travels would suggest. The fundamental unit of organisation according to Curr was the patriarchal family, with aggregations of families forming 'septs' (his equivalent of the Radcliffe Brown's later 'clan'), and aggregations of 'septs' forming the Bangerang 'race'. There was no formal system of government or control, no 'council of elders', no leaders or 'headmen' other than the family heads, whose authority stopped with the family itself. Yet despite this Curr ${ }^{11}$ spoke of the broad Bangerang groups being 'virtually one for the purpose of war'.

In contradiction of Robinson's unelaborated observations he paints a picture of strongly patrilocal residence within the territory of the 'septs' or, indeed, within even more localised territories of their constituent families.

10. See Russell McGregor's 1997 I magined D estinies - A boriginal A ustralians and the D oomed Race Theory, 1880-1939 for an excel lent general account. Tom Griffiths' H unters and Collectors, 1996, also contains relevant material.

11. 1968 [1883]:246-7. 
Curr, in The A ustralian race, provides the first attempt at a detailed map of Indigenous interests in the area.

It is apparent that Curr relied at least in part on the observations of others in his delineation of narrow group boundaries. Unfortunately he does not make his sources explicit. Furthermore there are substantial discrepancies in his placement of the eastern boundary for his 'Bangerang' group. The 1886 map in The A ustralian race misplaces the town of Cobram by approximately 16 kilometres. In Recollections, he places the eastern Bangerang boundary at Yarrawonga, rather than Cobram, another 20 kilometres or so to the east. Nowhere does he explain these discrepancies. Curr himself indicates in his text that his boundaries should not be seen as 'hard lines' but I am not aware, in fact, of anyone commenting on the discrepancies in Curr's delineation of his eastern boundary of the Bangerang before the present land-claim hearings.

This highlights one of the problems with much of the ethnographic source material in southeastern Australia (and other parts of the continent as well for that matter). Simply put, the authors had little reason to be concerned whether the locations which they provided for boundaries (or, for that matter, on other aspects of life as well) were strictly accurate. Curr did not produce his map with the intent of mapping real rights and interests, but rather as a Victorian gentleman pursuing intellectual games concerning a people whose interests he believed were no longer relevant. He was pursuing the Victorian fetish for collecting rather than seeking hard information for hard purposes.

In his Recollections of a Squatter, published in 1883, Curr reflected on the disappearance of the people who form such a central part of his book. At that time there were still many Yorta Yorta men, women and children living at Maloga Mission, on the edge of Curr's 'runs' of 40 years beforehand. Daniel Matthews (1881), the local missionary, complained in his diaries of the difficulties involved in 'civilising' them. Curr, however, was by this time too far away to have retained the intimacy of the frontier, that Griffiths has suggested separated those at the cutting edge from the gentlemen collectors ${ }^{12}$. It is noteworthy that two years earlier these same 'disappearing' people had petitioned the New South Wales Governor for land and would continue to press their claims throughout the following century.

Despite such questions, Curr's 'mapping' of boundary lines has had powerful effects. A map, no matter how questionably drawn, has a certain seductiveness about it. Here is something concrete in a situation of ambiguity. All four of the expert witnesses called by parties opposing the Yorta Yorta Bangerang land claim (Ron Brunton, Ken Maddock, Marie Fels and Bruce Sommer) cite Curr's map as a (or 'the') primary authority for the extent of their territories.

Once lines have been drawn on a map they attain a false concreteness that stands out from the complexities and ambiguities of reality. Boundaries between Indigenous groups are rarely so hard and fast. Even the most prominent of territorial mappers, N orman Tindale, ${ }^{13}$ refers to indeterminacies, 'shared' zones, and differences of perception. Myers speaks of 'territorial boundaries' in the Western Desert as 'highly flexible if not insignificant'. ${ }^{14}$ Ian Keen, writing of the M cLaren Creek area in the Northern Terri-

12. See Griffiths 1996: 54 for reflections on separation and intimacy in this context.

13. See Tindale 1974: $77 \mathrm{ff}$. 
tory, says that people of the area 'do not point out clear or unequivocal 'tribal' boundaries ... McLaren $\mathrm{Ck}$ people do not seem to define country by enclosing areas within boundaries, but rather by extension out from a focus'. ${ }^{15}$

Interestingly, the experts engaged by the opponents of the claim seem not to have noticed that the discrepancy between Curr's own different versions of 'boundaries' described in the text of his volumes are as great or greater than discrepancies in some other areas between Curr's descriptions and the claimants' own views. In the latter situations they saw such differences as highly significant. When the differences lay within Curr's own works (or between those of Curr and Barwick or Clark), however, they were instead seen as generally consistent.

Other players in the 19th century ethnography of the Yorta Yorta/ Bangerang are figures such as the assistant protectors Parker, Dredge and Le Souef, and the missionary Francis Tuckfield, in the early days of occupation; the ethnographers AW Howitt and RH Matthews and the missionaries Daniel Matthews and Thomas James, late in the century who all made contributions, but space prevents any serious consideration of their material here.

As the 19th century gave way to the 20th and ethnography to anthropology, much of the interests of 'Australianists' moved to the more remote parts of the continent. The largely dispossessed and, no doubt, dispirited people of southeastern Australia no longer provided the lure of supposed 'primitiveness', of difference, of exoticism, that they had originally engendered. Very little of the writings of people such as Curr, Matthews or Howitt relates directly to the situation of people at the time that they were writing. Instead they were interested primarily in the notion of an essential past, of A boriginal life as they saw it 'uncontaminated' by the actions of their white contemporaries. Northern Australia was thought to offer far better opportunities of this kind for those who were to follow them.

\section{Norman Tindale}

Although both Radcliffe Brown and Davidson made passing comments about the Yorta Yorta / Bangerang, it was not until N orman Tindale and Joseph Birdsell visited Cummeragunja in 1938 that the people were again exposed to significant anthropological investigation. Older members of the community still tell stories of the strange, unwell man who came to take photographs, measurements and family trees at a time when the community was in a state of foment over the actions of the manager of the day. They took him soup because they were worried about his health, but gave no thought to the idea that his published works might later, for better or worse, be of significance in their attempts to regain control of their traditional lands. As with Curr, at the time of the Maloga petitions for land, Tindale's published materials evince no interest in the community as it was at the time of his visit; simply in attempts at collecting the 'past'.

Tindale obtained some information about territorial matters from the Yorta Yorta/ Bangerang themselves and it seems likely that this was of significance in his 1940 Royal Society of South Australia map of tribal distributions. Healso relied on published mate-

14. Myers 1991: 93.

15. Keen 1997: 74-5. 
rials from Curr, Eyre, Smyth and Howitt. Interestingly, his 1940 map perhaps comes closest of the various recreations to reflecting the views of contemporary Yorta Yorta/ Bangerang people, and much closer than his better known 1974 work. None of the published sources which he cites dealt with the areas to the east between Yarrawonga and Albury. One can only assume that he obtained this information directly from the community itself.

Tindale cites RH Matthews al one as his sole justification for the identification of the Yorta Yorta (his J oti jota) as a separate group from the Bangerang. There is no doubt that he was wrong about this (all earlier sources identify Yorta Yorta or variants with people in the same place as 'Bangerang' groups, generally suggesting that it was a language or dialect name), but the myth has lived on in numerous subsequent local histories and other publications. It was not until Diane Barwick, and then Ian Clark, challenged his view more than four decades later that the poverty of evidence for the separation became clear.

Diane Barwick, along with Marie Reay, Jeremy Beckett, Malcolm Calley and a handful of others, played a major role in the revitalisation of anthropological interest in southeastern Australia in the late 1950s and 1960s.

Two major strands emerge from this period. Initially, perhaps for the first time since the early ethnographic fumblings of the Protectorate period, researchers attempted to look at Indigenous communities of the region as they were at the time rather than seeking to recreate information about a supposedly pristine past. The literature of this time often seeks to locate the people of the southeast within a more general international discourse on the situation of people in the Third World or other situations of colonial dispossession. In order to break free of the shackles of traditional anthropological interests this often meant downplaying the locally pertinent for the sake of emphasising the universal.

As time passed however, and as Indigenous groups became freer to pursue their own cultural interests with the death of 'assimilation' as the guiding light of official policy, writers such as Diane Barwick (one of the founding editors of A boriginal $\mathrm{H}$ istory) sought to understand the synthesis of traditional and contemporary aspects of Aboriginal life. One of Barwick's fundamental contributions in this period involved the rediscovery of materials such as the records of the Port Phillip Protectorate and the recognition of the importance of observations of writer such as Robinson. ${ }^{16}$

In the years immediately before her untimely death Barwick had begun an ambitious project to map local groups in Victoria. The first section of this work 'Mapping the Past, part 1 ' was published by A boriginal $\mathrm{H}$ istory in 1984. A second section, relating specifically to groups in the vicinity of the Yorta Yorta/ Bangerang claim area, was in preparation at the time of her death. Drafts of this material were kindly made available by Dr Richard Barwick in the course of the current claim hearing. In these works Barwick attempted to apply the conventional anthropological views of the day concerning social organisation to the data collected by Robinson and others.

16. Barwick 1984: 100-31. 
Barwick herself clearly recognised the tentative nature of such work, cautioning her readers to see it simply as a first step in a difficult process. In my view sheerred significantly in placing too much emphasis on 'narrow' groupings, and insufficient on broader interests and inter-relationships reflected in the writings not only of Robinson, but of others such as Parker and, later, Howitt. Her factual interpretations are also open to question on occasion, at least in the area of the current Yorta Yorta/ Bangerang native title claim - the area with which I am most familiar. On occasion she places great weight on snippets of information of dubious worth. In other situations she appears to be influenced as a result of taking sides in some of the great ethnographic brawls of the 19th century, most notably championing Howitt against RH Matthews. (By way of example, her southern boundary for the Yorta Yorta - much further to the north than is normally accepted - seems to have been solely based on an observation by H owitt, citing Kulin leader William Barak, whom he was interviewing in the vicinity of Melbourne, that one of the northern Kulin groups extended to 'near Mooroopna, near Shepparton.')

A major issue in the current native title claim involves her resurrection of the 'Waveroo' as a discrete group to the east of the Yorta Yorta/ Bangerang between Shepparton and Albury. Neither the location which she gives them as whole, nor the local groups which she identifies with them, accords well with Robinson's descriptions. One of the four sub- groups which she mentions is identified as a completely separate entity by Robinson (and as a Kulin group by Howitt). Two others may well simply be local groups identified as Bangerang by others, with different locative suffixes. Yet she cited no authority other than Robinson for their existence.

In a map of the region she locates this group neatly filling a gap to the east of Curr's 'Bangerang', but this only partially accords with the Robinson source data on which she depended.

Despite these problems, Barwick's 'Waveroo' are showing signs of becoming reified as a definite group in their own right. Ian Clark has used Barwick's map in his own publications dealing with the area, and at least one expert engaged by parties opposing the native title claim has cited his materials as corroborative of her position, though essentially he was simply relying on her own interpretation of the situation.

The Yorta Yorta/ Bangerang, and other neighbouring Indigenous groups, say simply that there never was a separate 'Waveroo' grouping, and that Robinson must have misunderstood the application of a descriptive term of another type (suggestions have been made that it may have been a moiety name or perhaps descriptive of particular environmental features). They find it remarkable that the uncorroborated evidence of one white man in the 1840s, reinterpreted inaccurately in the 1980s, can even be contemplated as standing against the weight of oral evidence handed down to them by their ancestors. Barwick, I suspect, would have been horrified to see work which she herself had described as "a gloss or "crib" for other scholars searching the archival evidence, in the hope that further work will expand and correct my attempt at mapping the past ${ }^{\prime 17}$ used in such a fashion.

17. Barwick 1984: 113. 
There is, of course, another side to all of this. Much of the academic material relating to the Yorta Yorta/ Bangerang claim area provides eloquent and effective support for the position of the contemporary claimants. It also helps to clarify some areas of doubt and confusion.

Nevertheless the examples given above help to highlight some important aspects of contemporary anthropological practice, regardless of whether the practitioner is working in the 'native title' sphere or not. Firstly we need to be very clearly aware that any materials which we produce may later be used for purposes quite different from those for which they were intended. Drawing lines on maps makes for effective presentation of aspects of Indigenous territoriality, but doing so may lead to situations which reify our own interpretations of reality, no matter how much we qualify them at the time, in situations of real importance to living people. We can overcome this problem to some extent by making clear the bounds of our own uncertainties, but even tentative conclusions and working hypotheses can all too easily come to be seen as 'facts' when given a patina of age and frequent repetition.

Wealso need to be humble about the extent of our own knowledge and of our discipline's ability to provide unequivocal answers, especially when seeking to undertake reconstructions of past lives, recognising that much of the source material that we use may well suffer significant defects either in observation or in interpretation.

Finally I believe that we need to be explicit about these problems, particularly in situations where issues of real consequence are at hand, such as in the presentation or analysis of materials in native title claim hearings.

\section{A codicil - the fate of the Yorta Yorta Claim}

This paper, in its original form, was prepared before the handing down of Justice Olney's judgement in 'The members of the Yorta Yorta A boriginal community $v$ the State of Victoria and others'. As most readers will be aware, Olney found against the Yorta Yorta. He did so largely on the basis that laws and customs identified by Edward Curr in his reminiscences about squatting life in the area (written 30 to 40 years after the event) were not reflected in materials relating to the community written by the missionary Daniel Matthews, concerning life in the area in the 1880s. The evidence, he said, was silent on such matters, but there was evidence which indicated disruption to traditional life:

118. The evidence is silent concerning the continued observance in Matthews' time of those aspects of traditional lifestyle to which reference is made in the passages quoted from Curr. Whether the former territorial areas of the various tribal groups were still recognised and protected as described by Curr is not something upon which there is any evidence. What the evidence does demonstrate is that the land on either side of the Murray had been taken up for pastoral purposes and that there had been both severe dislocation of the indigenous population and a considerable reduction in its numbers due to disease. Furthermore, there is no evidence to suggest that either Edward Walker or Kitty Atkinson/ Cooper, or their immediate descendants continued to acknowledge the traditional laws or observe the traditional customs of their forebears in relation to land. ${ }^{18}$

The implication of this, of course, is that silences in the evidence from non-Indigenous commentators at one time or another since white occupation have the potential to 
affect the recognition of traditional rights as much as errors or differences of view. Olney also cited the 1881 petition for land by the Yorta Yorta:

All land within (the petitioners') tribal boundaries has been taken possession of by the government and white settlers, a state of affairs which no doubt gave rise to their desire to change 'our old mode of life' in favour of 'settling down to more orderly habits of industry'.

He saw this as clear evidence that:

By 1881 those through whom the claimant group now seeks to establish native title were no longer in possession of their tribal lands and had, by force of the circumstances in which they found themselves, ceased to observe those laws and customs based on tradition which might otherwise have provided a basis for the present native title claim.

Olney recognised that 'Matthews would have played a part in the composition and presentation of the petition' but regarded it as a true expression of the beliefs of the community. Once this apparently fatal breach in continuity had been established, Olney concluded, native title had ceased to exist.

In fact the petition appears to have been written in Sydney by Matthews, while seeking support for the community, without any recourse to the words or thoughts of those community members whose names were actually attached to it. The petition ${ }^{19}$ was presented in early July 1881. Matthews arrived in Sydney on 29 A pril 1881 and left on 3 August 1881. He was not accompanied by people from $M$ aloga. There are frequent references in his diary for this period of 'working on the papers' etc with Mr Palmer. ${ }^{20}$ It seems reasonable to draw the inference that the petition was really totally the work of Matthews and Palmer.

The decision was subsequently appeal ed by the Yorta Yorta to the full bench of the Federal Court. All three members of the bench were critical of aspects of Olney's approach to the case, most notably the weight which he placed on the 1881 petition. They also pointed towards elements of Olney's judgement which came close to adopting a 'frozen in time' view of traditional law and custom, contrary to the intent and proper interpretation of the native title legislation. Despite this, two of the three judges upheld Olney's judgement. A third judge, Chief Justice Black, found in favour of the Yorta Yorta and would, if he had been in the majority, have ordered that the matter be reconsidered. ${ }^{21}$

At the time of going to press, the Yorta Yorta have obtained leave to appeal to the High Court of Australia. The hearing has been set down for late May 2002.

18. OIney J. 'The members of the Yorta Yorta A boriginal community $v$ the State of Victoria and others', VG no 6001 of 1995.

19. Which appears as A ppendix 10 of N ancy Cato's M r M aloga, $1976 \mathrm{ed}$.

20. J Matthews diaries, M ortlock Library of South Australia PRG 359/ 2 (typescript version).

21. Black C.J., Branson and Katz J.J., 'M embers of the Yorta Yorta A boriginal community v State of Victoria and others V 34 of 1999, 8 February 2001. 


\section{References}

A tkinson, W. 1981, A picture from the other side, unpublished typescript, Melbourne.

_ 2000, 'N ot one iota: the Yorta Yorta struggle for land justice', PhD thesis, Law and Legal Studies, La Trobe University [Melbourne].

Barwick, D. 1972, 'Corranderk and Cummeragunja: pioneers and policy', in Epstein, T.S. and Penny, D.H. (eds) 0 pportunity and response: case studies in economic development, Hurst.

_ 1984, 'Mapping the past: an atlas of Victorian clans 1835-1904. Part 1', A boriginal History 8(1-2): 100-31.

Black, C.J., Branson and Katz J.J. 'Members of the Yorta Yorta A boriginal community v State of Victoria and others', V 34 of 1999, 8 February 2001.

Cato, N. 1976, M ister M aloga, University of Queensland Press, St Lucia.

Curr, Edward M. 1886-87, The A ustralian race: its origin, languages, customs, places of landing in A ustralia, and the routes by which it spread itself over that continent, 4 vols, Victorian Government Printer, Mel bourne.

_ 1965, Recollections of squatting in V ictoria from 1841 to 1851, Mel bourne University Press, Melbourne (edited version).

— 1968 [facsimile of 1883 edition] Recollections of squatting in V ictoria from 1841 to 1851, State Library of South Australia, Adelaide.

Goodall, H. 1996, Invasion to embassy: Land in A boriginal politics in N ew South Wales, 1770-1972, Allen \& Unwin.

Griffiths, Tom 1996, H unters and collectors, Cambridge University Press.

Hiatt, L. 1996, A rguments about A borigines: A ustralia and the evolution of social anthropology, Cambridge U niversity Press, Cambridge.

Keen, I. 1997, 'The Western desert vs the rest', in Merlan, F, Morton J, and A Rumsey (eds) Scholar and sceptic: A ustralian A boriginal studies in honour of LR H iatt Canberra, A boriginal Studies Press.

Matthews, J. 'Diary for 1881', Mortlock Library of South Australia PRG 359/ 2 (typescript version).

McGregor, R. 1997, Imagined destinies - A boriginal A ustral ians and the doomed race theory, 1880-1939, Melbourne University Press, Melbourne.

Myers, F.R. 1991, Pintubi self, Pintubi country, Berkeley.

Olney, J. 'The members of the Yorta Yorta A boriginal community $v$ the State of Victoria and others', VG No 6001 of 1995.

Radcliffe-Brown, A. 1914, 'Threetribes of Western Australia', R oyal Anthropological Institute Journal 43: 143-194.

Tindale, N.B. 1940, 'Distribution of Australian A boriginal Tribes: a field survey', Royal Society of South A ustralia, Transactions, 64: 140-231 plus map.

Tindale N.B. 1974, A boriginal tribes of A ustralia: their terrain, environmental controls, distribution, limits, and proper names ANU Press, Canberra. 